Arboriculture \& Urban Forestry 2016. 42(1): 21-30

\title{
The Linear Index of Tree Appraisal (LITA) Model for Economic Valuation of Large Urban Trees in Sweden
}

\author{
Johan Östberg and Johan Sjögren
}

\begin{abstract}
Economic valuation of urban trees is important for their management and to ensure that such trees are maintained and protected. However, numerous models for valuing urban trees are currently available, which has led to great variation in the final price. It has also resulted in multiple models being used within the same country, thus confusing the courts. Against this background, researchers examined whether the horizontal cross-sectional area of the tree should be used as the basis for extrapolating tree replacement cost in a linear fashion. Researchers also developed a model, the Linear Index of Tree Appraisal (LITA) model, which uses tree cross-sectional area to extrapolate from a band of known prices to a base price for any desired tree size, which can then be adjusted using an appropriate factor depending on tree vitality/damage.

The LITA model is easy to use and to update, does not have any limitations concerning tree species or sizes, and does not rely on subjective judgments except in assessment of tree damage. It provides a simple method for determining the replacement cost of urban trees and is thus designed to work where 'soft' values are sometimes difficult to justify.

Key Words. Appraisal; Management; Scandinavia; Sweden; Tree Valuation; Urban Trees.
\end{abstract}

Trees contribute to the delivery of many ecosystem services in urban areas, such as moderation of local climate (Nowak et al. 2001a; Yokohari et al. 2001; Dimoudi and Nikolopoulou 2003; Nowaketal.2006), stormwater management (Bolund and Hunhammar 1999; Xiao and McPherson 2002), recreation and human well-being (Todorova et al. 2004), and cultural value (Alcamo et al. 2003). Protection of trees is therefore crucial for sustainable urban development.

Economic valuation has been used for a long time (McMillan 1964; Helliwell 1967; Lewis 1970; Kinnard 1971) and for numerous purposes. These purposes include use in strategies for private funding of trees (Kuchelmeister 2000); in order to demonstrating the benefits of urban trees and how much these ecosystem services represent in monetary terms (McPherson and Peper 1996; McPherson et al. 1997; Nowak et al. 2008; i-Tree 2012); as justification for demanding more funding for urban trees (Dwyer et al. 1992); in developing and evaluating programs for managing urban trees (Nowak et al. 2002); in calculating potential losses caused by highly damaging agents (Nowak et al. 2001b), such as the Asian longhorned beetle and emerald ash borer (Raupp et al. 2006; Ball et al. 2007); for protection of trees during construction work (Glaeser 2010); and in court cases when trees are cut down or pruned unlawfully (Bulír 2009). Economic valuation can hence be an important part of the managing urban trees and ensuring that urban trees are maintained and protected (Nowak et al. 2002).

There are currently several different ways of placing an economic value on trees, e.g., through "willingness to pay" (Zhang and Zheng 2011), ecosystem contributions (i-Tree 2012), and formula methods (Price 1995). The formula methods are the most common way of economically valuing individual trees and are also the easiest type of method to implement. These models calculate tree value based on tree replacement cost in a variety of ways (Moore 1992; CTLA 2000; Cullen 2002; Randrup 2005; Helliwell 2008). The fundamental principle of most models is that a base cost is calculated first, followed by an adjustment depend- 
ing on other factors; e.g., tree placement, vitality, damage, or aesthetics (Moore 1992; CTLA 2000; Cullen 2002; Randrup 2005; Helliwell 2008). Some models allow an increase in the base cost if the tree has aesthetic characteristics (Randrup 2005), while others only decrease the base cost (CTLA 2000). The possibility of increasing the value based on amenity is also something that has been discussed (Cullen 2002), the conclusion being that amenity values should only decrease the economic value.

The method used to calculate the base value also differs between models. Some use fixed base values that are regulated by a central committee (Helliwell 2008), othersarebased on plant nursery prices (Moore 1992; Randrup 2005; CAVAT 2010). The base values are then scaled up depending on tree size, a method that also varies between models. For example, some base values are based on stem circumference (Randrup 2005), others on cross-sectional area (CTLA 2000; CAVAT 2010) or tree volume (Moore 1992).

As for the base cost calculation and the adjustment factors, consideration of tree age also differs between models. In some models, the value decreases if the tree has reached a certain age (Randrup 2005; Bulír 2009), but there is disagreement regarding when the reduction due to tree age should take effect, how steep the reduction slope should be, and how maximum tree age should be valued (Randrup 2005; Bulír 2009).

In the seven existing models reviewed herei.e., CAVAT (2010), CTLA (2000), Helliwell (2000), the Koch method (Bulír 2009), the revised Burnley method (Moore 1992), STEM (Flook 1996), and VAT03 (Randrup 2005) - some form of reduction is made due to damage and/or reduction of vitality. This is the only parameter that forms part of all these models and it only reduces the economic value of the tree. There are differences in how damage and/ or vitality are defined, but usually several separate parameters together give a total score concerning damage and/or vitality (Flook 1996; Randrup 2005).

The variations in calculating the base cost, scaling, and adjusting the factors lead to wide variation in the final value (Watson 2002). The profusion of models has also resulted in a situation where several different models are used within the same country, consequently confusing the courts (Randrup 2005). A trend has also been noted for courts in Sweden to question aesthetic value [e.g., Lämna $v$ Tellstig
(2008) and Lämna v Tellstig (2010), where the District Court and Court of Appeals made different conclusions on the aesthetic values of the same trees], which in some models can account for the majority of the total value (Randrup 2005). There is thus a need for a simple model that is easy to explain and update, and that does not rely on 'soft' values, such as aesthetics, architectonics, and growing site.

The aim of this study was therefore to develop a model that is easy to assess and understand, and that can work well within the Swedish legal system. The purpose of the model is to calculate the replacement cost of a tree of the same species, location, and condition as the tree being valued, using the cross-sectional area to extrapolate, from a band of known prices, to a base price for any desired size that can then be adjusted using appropriate factors.

\section{MATERIALS AND METHODS}

In constructing a tree appraisal model, in the present case for Sweden, it was deemed important to have clear goals for the model. Three points were considered to be of key importance: 1) The model should reflect the change in the market price with respect to tree size for a specific tree species; 2) the calculated tree price should be based on the lower base value option, in order to limit the impact of accusations that the extrapolation resulting in the tree replacement cost is an overestimation; and 3) each step in the model should be simple to explain to the courts and to users.

The research was divided into three main tasks: i) finding a way to calculate a base cost based on tree nursery prices that would reflect the market price of urban amenity trees, ii) finding and describing appropriate adjustment factors, and iii) finding a model for calculating the planting costs for common planting conditions.

\section{Plant Nursery Prices for Trees}

The base cost calculation was based on tree nursery prices in accordance with VAT03 (Randrup 2005), CAVAT (2010), and the revised Burnley method (Moore 1992). Data were obtained from six tree nurseries (three German and three Swedish). These plant nurseries were selected through a questionnaire that was sent out to 14 cities, housing companies, and cemeteries in Sweden that had previously shown an interest in the question of economic 
valuation of urban trees. The response rate was $57 \%$. The survey consisted of one main question: Which plant nurseries do you mainly buy trees from?

The six tree nurseries used for base value calculation were chosen from the list of nurseries mentioned in responses in order to represent international tree nurseries and the most popular Swedish nurseries. The chosen nurseries are listed below in alphabetical order, with the nursery catalog printing year included in parentheses.

- Billbäcks, Sweden (2012)

- Bruns Pflanzen, Germany (2011)

- Lappen, Germany (2012)

- Lorenz von Ehren, Germany (2012)

- Splendor Plant, Sweden (2012)

- Stångby, Sweden (2012)

\section{Tree Species}

The tree species selected for calculation of the base value were the three most common urban tree species in the Nordic countries, according to Sjöman et al. (2012). These were Acer platanoides L., Betula pendula L., and Tilia $\times$ europaea L. Accurate taxonomic identification of the species was carried out according to Aldén and Ryman (2009). In addition, a fourth species, Quercus robur L., was chosen due to its comparatively large price deviation from the other three species, with a higher price in all tree nursery catalogs. More in-depth analysis was conducted on Tilia $\times$ europaea due to its dominance in urban Nordic environments, where it occurs with a mean frequency of $16.0 \%$ (Sjöman et al. 2012).

\section{Data Analysis}

The cross-sectional area for each tree size considered was measured in square centimeters $\left(\mathrm{cm}^{2}\right)$ and calculated from the given circumference (at 1 $\mathrm{m}$ height, in accordance with Swedish and European nursery standards), on the assumption that a circular trunk shape is an adequate approximation. This procedure yielded a data set with price as a function of tree trunk area for each of the selected tree species (Acer platanoides, Betula pendula, Quercus robur, and Tilia $\times$ europaea). Linear functions were fitted to the data using the Proc GLM procedure in the statistical software SAS 9.2 (SAS Institute Inc., Indianapolis, Indiana, U.S.). These fits were obtained for each individual species. The goodness-of-fit/coefficient of determination $\left(\mathrm{R}^{2}\right)$ was also calculated, again using the SAS software. In addition, linear and polynomial functions were fitted to the original circumference versus price data.

A linear model for tree price as a function of its trunk cross-sectional area [the Linear Index of Tree Appraisal (LITA) model] was developed inspired by these fits, to allow for extrapolation to large tree sizes from a single data point.

\section{Tree Planting Costs}

The tree planting costs were calculated using a calculation system for outdoor constructions (KP-Kalkyl 2012), with the results verified through contacts with municipal authorities and contractors in Sweden. The items included in the tree planting costs in the model are in accordance with CTLA (2000) and VAT03 (Randrup 2003). Inspired by VAT03 (Randrup 2003), the following costs were included:

- Removal of the damaged tree (trunk, branches, and roots), excluding the sale of wood

- replacement of soil

- restoration of the growing site

- planting of new trees

- establishment of aeration and irrigation systems and tethering

- restoration of surface pavings and other surrounding areas

- maintenance of the tree for five years

\section{RESULTS AND DISCUSSION}

\section{Circumference or Cross-Sectional Area}

Regarding the relationship between tree price and tree circumference, for the data obtained from the nurseries, a linear and a second order polynomial both proved to be good fits to the Tilia data $\left(\mathrm{R}^{2}=0.970\right.$ and 0.994 , respectively) (Figure 1). A noteworthy feature of the linear fit was the large constant offset. It was also found that the three most common species of trees were very similar in their price behavior, and therefore, for reasons of clarity, only the Tilia data are shown in Figure 1 and Figure 2. Quercus robur deviated as expected by being consistently more expensive, but the general shape of the curve was similar.

Similarly, a second order polynomial and a linear function of the cross-sectional area gave a good fit to the data for all individual species 
$\left(\mathrm{R}^{2}=0.990\right.$ and 0.997, respectively) (Figure 2). The three common species were very similar in this case too, while Quercus robur again deviated by being more expensive. It is important to note that the constant factor in the linear case was comparatively small, which was a general feature for all tree species studied. The LITA model is therefore based on the approximation that this constant factor can be neglected.

The reason for choosing tree cross-sectional area, as opposed to tree circumference, as the basis for linear extrapolation is perhaps not immediately clear, especially since a linear function was a very good fit in both cases (Figure 1; Figure 2). The choice stemmed from a desire for simplicity and for the ability to extrapolate from a single or a few data point(s). If the constant factor in the linear extrapolation function is zero, then the extrapolation is determined only by the gradient, which greatly simplifies calculation. Perhaps the most important feature is that it simplifies without significant loss of accuracy. In fact, forcing the fitted cross-sectional function to have a zero constant term changed the goodness-of-fit only slightly (Figure 2), while in the case of tree circumference it decreased it substantially (Figure 1).

Another possible parameter instead of circumference and cross-sectional area could be tree volume or mass, but these are more complicated to compute due to the need for data on factors such as tree height and density. Such a model would have to rely on estimated data and would thus be more complicated to explain in a court situation than data based on cross-sectional area. However, the best argument against using higher-order parameters is that it is clear from the data that this will never yield a substantially more accurate description.

The final price calculated by the LITA approach depends on the choice of size, or more correctly, on the price per $\mathrm{cm}^{2}$ of that size, which is used as the starting point of the extrapolation. This is the primary parameter in the LITA approach and has a much larger impact than the 'zero constant' assumption. There are naturally some variations in price per $\mathrm{cm}^{2}$ for the tree sizes available in commercial nurseries. In the case of Tilia $\times$ europaea, the lowest price per $\mathrm{cm}^{2}$ can be found for size 12-14 (measured according to

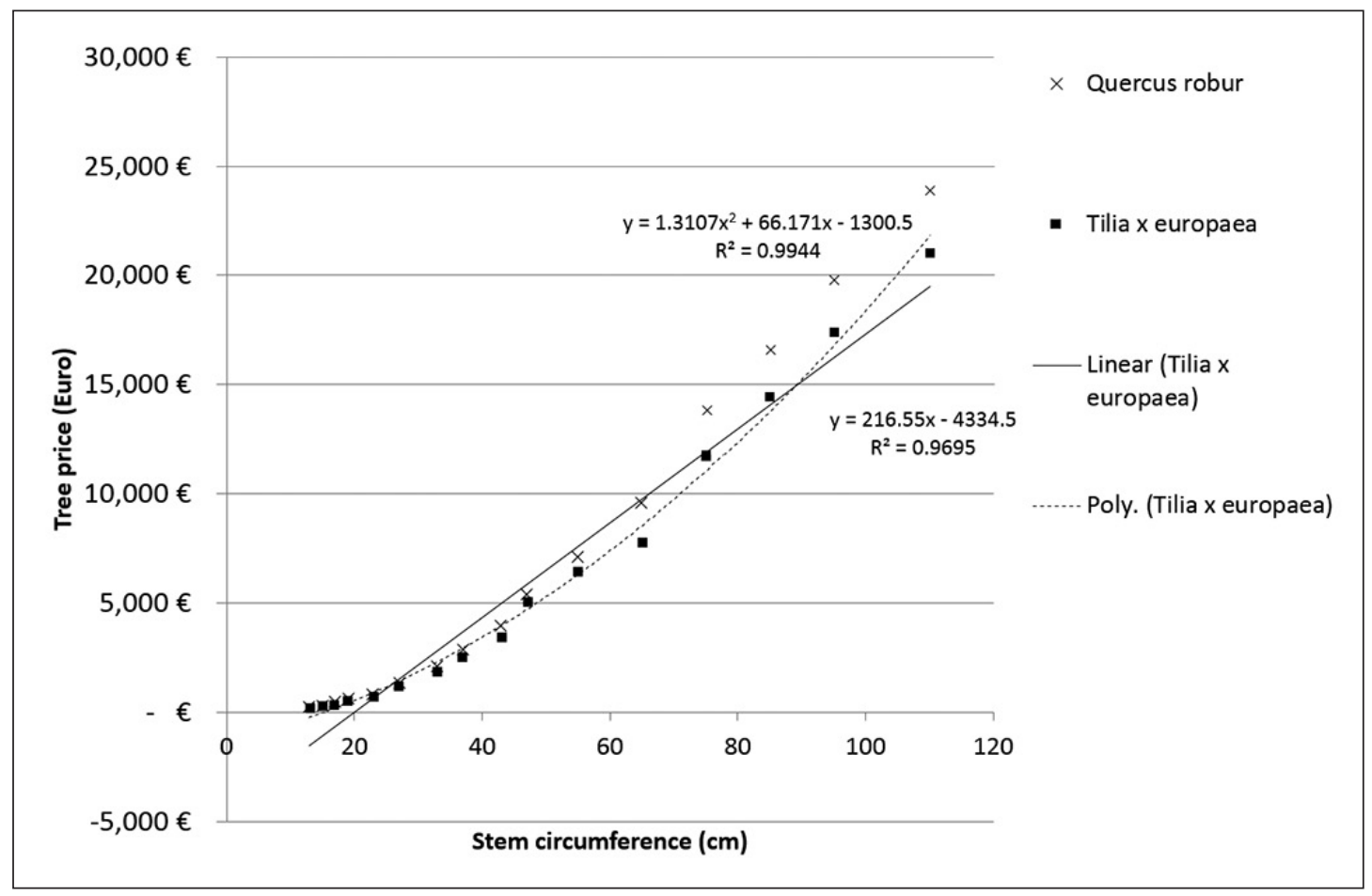

Figure 1. Tree price as a function of stem circumference at $1 \mathrm{~m}$ stem height (in accordance with tree nursery standards) for Acer platanoides, Betula pendula, Quercus robur, and Tilia $\times$ europaea. The linear and second order polynomial functions for Tilia $\times$ europaea are also shown. 


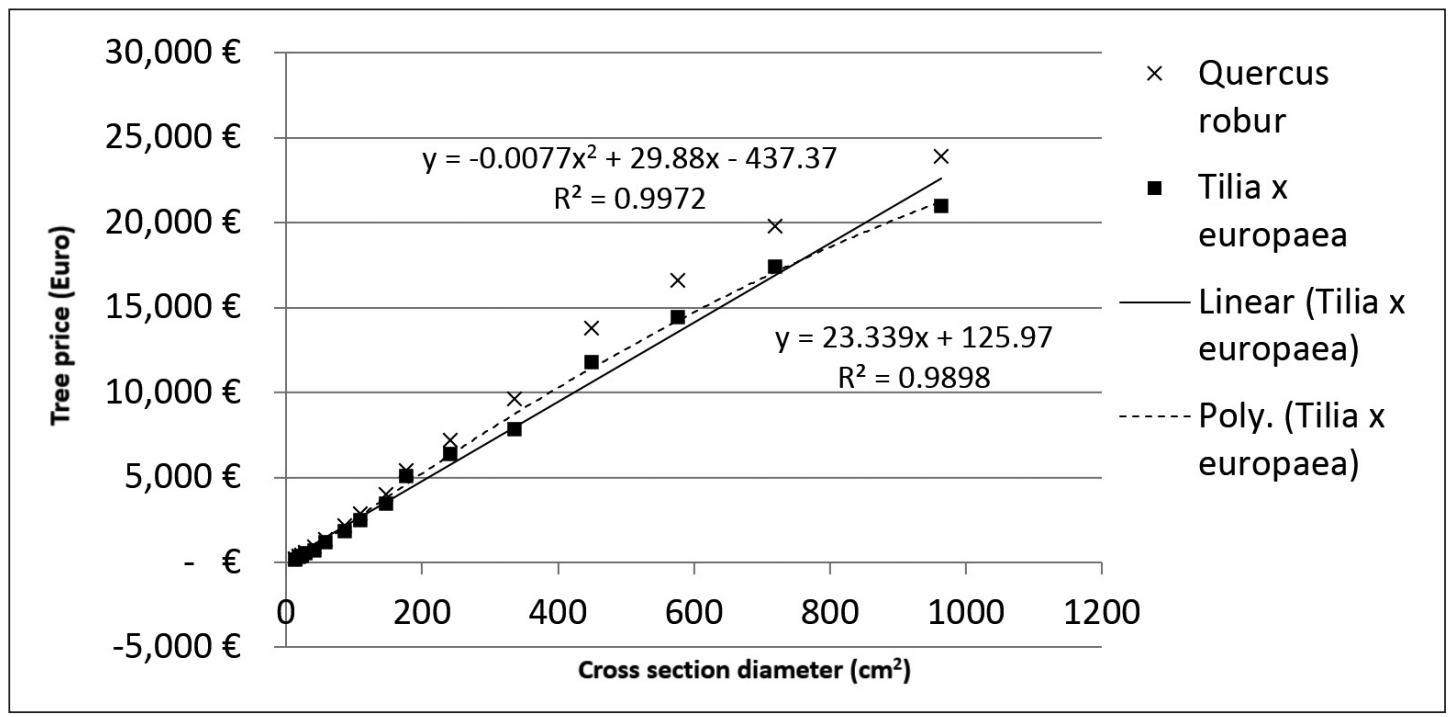

Figure 2. Tree price as a function of cross-sectional diameter at $1 \mathrm{~m}$ stem height (in accordance with tree nursery standards) for Acer platanoides, Betula pendula, Quercus robur, and Tilia $\times$ europaea. The linear and second order polynomial functions for Tilia $\times$ europaea are also shown.

European tree nursery standards as stem circumference at $1 \mathrm{~m}$ height), and the highest for size 45-50 (stem circumference at $1 \mathrm{~m}$ height). Trees of size 12-14 are almost always available in nurseries and, for all species, have the lowest, or among the lowest, price per $\mathrm{cm}^{2}$. In line with the goal that calculated tree price should be based on the lower base limit of the value produced by the method, the cost per $\mathrm{cm}^{2}$ should therefore be based on that of size 12-14. On applying the LITA model and comparing the results against existing data, it emerged that only in rare cases did the proposed LITA base price exceed the nursery price. For Tilia $\times$ europaea the price was never overestimated but rather underestimated, by $33 \%$ on average, for all tree sizes available in the tree nursery catalogs studied here. In the vast majority of cases, the price for other species was also underestimated (Table 1).

As stated, the LITA model uses only one tree size (12-14) from which to extrapolate. This makes the model simple to update, owing to the large number of tree nurseries that have this plant size in stock, and it is very easy to work with. A possible alternative to the one-point approach would be to use the mean value of all data points or of some carefully selected subset of points. However, this would make the LITA model difficult to update and could make it dependent on the verdict of committees or steering groups, and thereby not in compliance with the three goals initially set for the tree appraisal model.

The production methods used in nurseries and their influence on price vary, and therefore basing economic valuations on tree nursery prices is reported to be problematic because of the effects of production method on total price of the tree (Hegedüs et al. 2011). One of the examples cited in that study concerns tree species that are propagated only by grafting, which have a higher price because of the increased use of manpower in their propagation. The LITA model will be affected by this, but it is how the commercial tree market works, and it is difficult to find a market that would better describe tree replacement cost. This was also recognized by Hegedüs et al. (2011), who noted that it is difficult to avoid the use of nursery prices. However, the final differences in tree prices in the current study were not very large, either in the tree nursery catalogs or the calculated replacement cost (Table 1). Thus, although the problems arising from using tree nursery figures seem serious, they will only have a limited effect on the model and calculated replacement cost.

\section{Adjustment Factors}

The base cost calculated in the LITA model is for a tree without damage and without loss of vitality, since this is the state in which trees are bought from nurseries. However, the tree being replaced may very 
Table 1. Calculations showing the price (€EUR) per unit cross-sectional area $\left(\mathrm{cm}^{2}\right)$, the actual price (€EUR) in tree nurseries, the base price (€EUR) calculated using the LITA model, and the amount and percentage by which the LITA price differs.

\begin{tabular}{|c|c|c|c|c|c|}
\hline $\begin{array}{l}\text { Tree circumference } \\
\text { at } 1 \mathrm{~m} \text { height }\end{array}$ & $\begin{array}{l}\text { Price per } \mathrm{cm}^{2} \\
\text { cross section }\end{array}$ & $\begin{array}{l}\text { Mean price in } \\
\text { tree nurseries }\end{array}$ & $\begin{array}{l}\text { Calculated value } \\
\text { (using size } 12-14 \text { ) }\end{array}$ & $\begin{array}{l}\text { Difference } \\
\text { in price }\end{array}$ & $\begin{array}{l}\text { Difference } \\
\text { in } \%\end{array}$ \\
\hline $12-14$ & $14 €$ & $190 €$ & $190 €$ & $-€$ & $0 \%$ \\
\hline $14-16$ & $16 €$ & $281 €$ & $253 €$ & $28 €$ & $10 \%$ \\
\hline $16-18$ & $16 €$ & $377 €$ & $325 €$ & $52 €$ & $14 \%$ \\
\hline $18-20$ & $18 €$ & $524 €$ & $406 €$ & $117 €$ & $22 \%$ \\
\hline $20-25$ & $17 €$ & $706 €$ & $595 €$ & $111 €$ & $16 \%$ \\
\hline $25-30$ & $21 €$ & $1209 €$ & $821 €$ & $388 €$ & $32 \%$ \\
\hline $30-35$ & $21 €$ & $1827 €$ & $1226 €$ & $602 €$ & $33 \%$ \\
\hline $35-40$ & $22 €$ & $2423 €$ & $1541 €$ & $882 €$ & $36 \%$ \\
\hline $40-45$ & $24 €$ & $3569 €$ & $2081 €$ & $1488 €$ & $42 \%$ \\
\hline $45-50$ & $30 €$ & $5276 €$ & $2486 €$ & $2790 €$ & $53 \%$ \\
\hline $50-60$ & $28 €$ & $6626 €$ & $3405 €$ & $3221 €$ & $49 \%$ \\
\hline $60-70$ & $24 €$ & $8069 €$ & $4755 €$ & $3314 €$ & $41 \%$ \\
\hline $70-80$ & $27 €$ & $12176 €$ & $6331 €$ & $5845 €$ & $48 \%$ \\
\hline $80-90$ & $26 €$ & $14939 €$ & $8132 €$ & $6806 €$ & $46 \%$ \\
\hline $90-100$ & $25 €$ & $18001 €$ & $10158 €$ & $7843 €$ & $44 \%$ \\
\hline $100-120$ & $23 €$ & $21735 €$ & $13619 €$ & $8116 €$ & $37 \%$ \\
\hline Mean & $22 €$ & - & - & & $33 \%$ \\
\hline
\end{tabular}

Table 2. Adjustment factors in the LITA model for adjusting tree price downward due to damage to tree crown volume, stem circumference, or root system spread. Based on the Koch method (Bulír 2009).

\begin{tabular}{ll}
\hline $\begin{array}{l}\text { Percent damage to tree crown } \\
\text { volume, stem circumference, } \\
\text { or root system spread }\end{array}$ & $\begin{array}{l}\text { Percent reduction in } \\
\text { economic value }\end{array}$ \\
\hline$<20 \%$ & Up to $20 \%$ \\
Up to $25 \%$ & At least $25 \%$ \\
Up to $30 \%$ & At least $35 \%$ \\
Up to $35 \%$ & At least $50 \%$ \\
Up to $40 \%$ & At least $70 \%$ \\
Up to $45 \%$ & At least $90 \%$ \\
$>50 \%$ & $100 \%$ \\
\hline
\end{tabular}

well have damage and loss of vitality, and the valuation will not be credible unless this is accounted for. This is why a depreciation factor is included in the LITA model to adjust the base cost of the tree. Use of depreciation parameters, based on damage and loss of vitality, is common in existing evaluation models (CTLA 2000; Helliwell 2000; CAVAT 2010), but the actual parameters used vary between models.

The adjustment factor in the LITA model is based on the Koch method (Bulír 2009) and is in line with Swedish tree inventory standards (Östberg et al. 2012). It consists of three parts: tree crown, trunk, and root system. Depending on how much damage has occurred to these individual parts of the tree being replaced, a reduction in the total value of the tree is calculated according to set percentages (Table 2).

The Koch method was chosen due to the rather clear recommendations on percentages and the subdivision of the tree into zones (roots, stem, and crown), which are easy to understand and already accepted by Swedish tree officials. Inclusion of existing and accepted parameters means that the model is likely to be accepted more readily and does not require additional tree inventories if a city chooses to calculate the overall replacement cost of its urban tree stock.

In some models for the economic evaluation of trees (Randrup 2005; Bulír 2009), estimated age or expected lifetime of the tree is included as a parameter. These parameters are intended to reflect a natural progression where a tree with only a few years to live is given a reduced value, while a tree that has a long time left is given an unreduced or even increased economic value. It could also be argued that the age factor is a way of acknowledging the future benefits and contributions of the tree rather than the actual appearance it has today or the significance it has. As Cullen writes, "This notion of anticipation or expectation is important. The past is gone. It is only the future benefits that have remaining utility" (Cullen 2007, pp. 30). There are several problems with adopting this notion of urban trees. The first is that focusing on future contributions implies that a younger tree has a higher value than an older tree, as it will probably have a longer time to contribute future benefits than an older tree. The second problem rests in identifying how old the tree is and predicting how long it will keep contributing and thereby giving these future benefits. Different tree species have 
different life expectancies, but life expectancy is a blunt instrument to use because of the large variation even among individuals of the same species. In extreme cases, the difference between individuals can be more than 100 years. Tree age is therefore problematic to introduce into some type of economic depreciation, which is really only intended to comply with any other objective change that the courts are accustomed to value, such as material goods or similar, comparatively short-lived objects. Tree age is important, of course, but in the LITA model it is instead reflected in the damage and vitality parameters. When a tree is reaching the end of its life, it is likely to have damage, or at least diminishing vitality, thus reducing its value. Conversely, if the tree does not have damage or loss of vitality, there is nothing to show that it is nearing the end of its life. For this reason, there is no estimate of tree age in the LITA model, and by omitting a specific tree age factor, the model remains simple.

Some models use soft values (e.g., aesthetic, architectonic, and recreational values) that increase or decrease the value of the tree (Randrup 2005). Studies have also shown that citizens' willingnessto-pay and their attachment to urban trees are connected with the aesthetic attributes of these trees (Zhang and Zheng 2011). It might therefore seem surprising that no adjustment is made for these soft values in the LITA model. These values are important to take into consideration when a city council is choosing (e.g., which trees should be saved in a development context) and when promoting urban trees to the public. However, inclusion of aesthetic and architectural parameters in all economic models raises two questions that are difficult to answer, namely: 1) To whom is the tree aesthetically and architecturally beautiful? and 2) Who should judge whether this is the right opinion? These two questions are crucial in aesthetic and architectural valuation, which can cause problems. Courts can perceive these values differently, even in the same case in different instances, as seen in court cases in Sweden [e.g., Bergin v Geisel (2009) and Bergin v Geisel (2010)], where the District Court and Court of Appeals reached different conclusions on the aesthetic values of the same trees). Sometimes the path chosen is to disregard these values because of the problems in judging them neutrally [e.g., Pohland $v$ Värnamo municipality (2012)], where the court chose to disregard the aesthetic value). However, the aesthetic, cultural, and location characteristics of a tree are important in the sense that the courts use these to demonstrate that the trees are not commercial forest and to determine the compensation to be paid [e.g., Pohland v Värnamo municipality (2012), where the aesthetic value was used to determine whether the trees were commercial forest or not].

\section{Planting Costs}

When it comes to calculating the costs of planting a tree, there are many factors to consider:

- the number of trees to be planted or managed

- the specific requirements of the planting site (e.g., the size of the planting bed, the number of layers in the structure, and the paving type, such as concrete or asphalt)

- odd and difficult placements, which can radically affect, for example, the costs of construction and transportation to the site

- the cost of caring for replacement trees during the initial years of their life

The list of special conditions is almost limitless, but the general assumption was that it is not reasonable to create a model that calculates an exact cost for the planting and maintenance of replacement trees for every conceivable scenario. Obtaining a standard planting cost per $\mathrm{cm}^{2}$ for a tree requires a simplified model, which in turn leads to a classic dilemma-the model should reflect reality in a reasonable way, but should not be linked too precisely to tree replacement in the individual case. The LITA model is therefore a compromise that allows the planting costs to be included when calculating a replacement cost for urban trees. If a value is required for particularly demanding planting sites, or for sites regarded as more labor demanding, then a case-specific estimate must be made.

For common planting conditions, the cost per tree increases step-wise (Figure 3). This is especially noticeable for large trees. Nonetheless, a linear function captures most of the behavior in the costs for street planting and park planting $\left(\mathrm{R}^{2}=0.804\right.$ and 0.810 , respectively). These two cases are very similar, however, so the combined mean is used in the LITA model. 


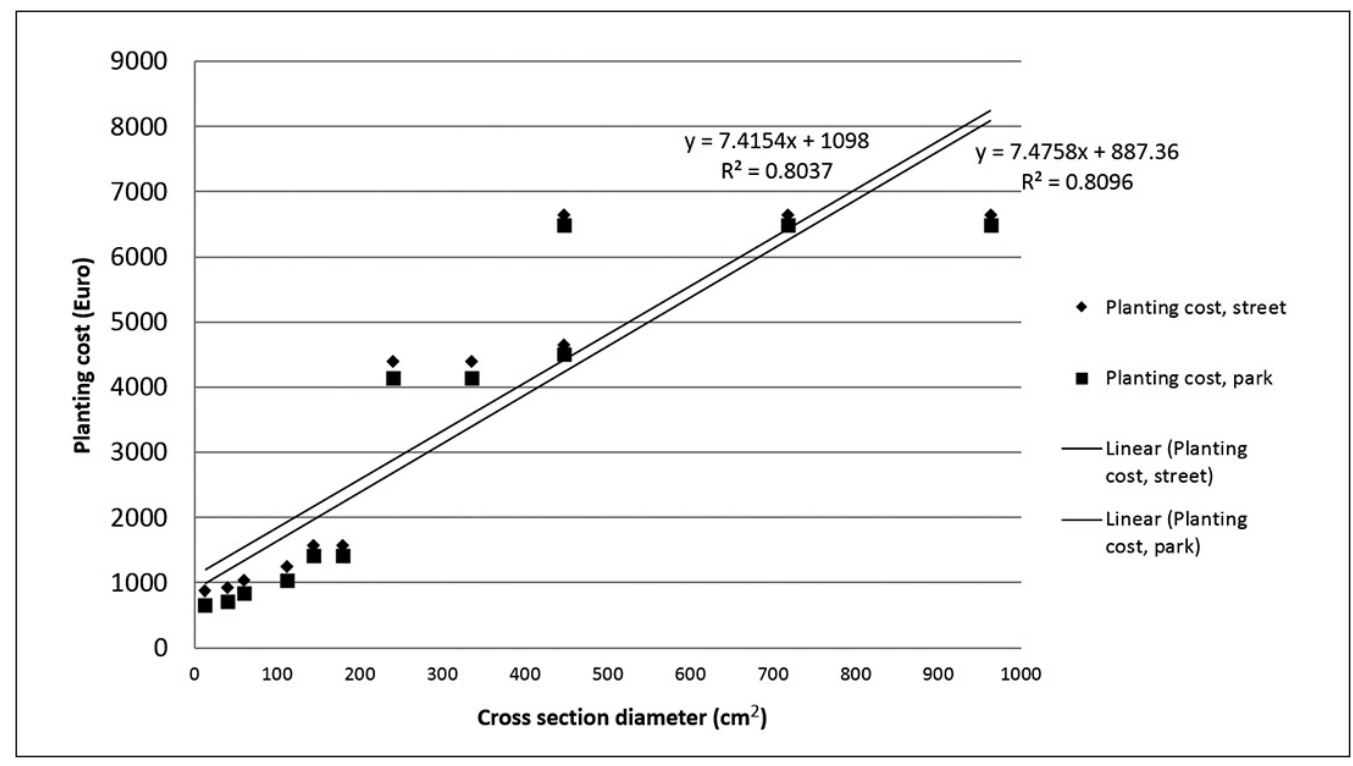

Figure 3. Tree planting costs, based on the mean planting costs for trees in street and park environments.

\section{The Final Formula}

Having specified the replacement cost of the tree based on the cross-sectional area, the adjustment factors, and the planting costs as described in this article, the proposed formula for calculating the value is:

$$
\mathrm{Vr}=\mathrm{Pt} \times \mathrm{A} \times \mathrm{D}+\mathrm{A} \times \mathrm{Pp}+\mathrm{B}
$$

where $\mathrm{Vr}$ is the total replacement cost; $\mathrm{Pt}$ is the nursery catalog price per $\mathrm{cm}^{2}$ for a tree of size 12-14 and of the same tree species as the tree being replaced; $A$ is the crosssectional area of the tree being replaced $\left(\mathrm{cm}^{2}\right) ; \mathrm{D}$ is the reduction due to damage to the tree being replaced; $\mathrm{Pp}$ is the planting cost per $\mathrm{cm}^{2}$; and $\mathrm{B}$ is the base planting cost.

The LITA approach is a solid way of calculating a replacement value, is easy to update and explain, and has a clear link to the marketplace for trees (i.e., tree nurseries). The model also produces an economic replacement cost for specific trees, although replacement cost is not necessarily equal to value (CTLA 2000). A replacement tree, although of the same size, species, and condition, will not have the same value as the tree being replaced (i.e., it will not have the same history or architectural features that the lost tree might have had). Hence, the economic valuation made by the LITA model and the adjust- ment factors proposed in the model will never fully replace the lost value of the original tree.

The LITA model is designed to evaluate large trees and to err on the side of underestimation. As a result, the calculated replacement cost will not be the best option for smaller trees that are available from nurseries. Such smaller trees, in most cases, will be allocated a lower replacement cost than the nursery price, due to the decision to base the model on the lowest price per $\mathrm{cm}^{2}$. In short, calculated costs are not meant to replace nursery prices when such exist, as with the LITA model this will most likely result in a lower replacement cost. In fact, it may also underestimate the cost for sizes just slightly above those available from nurseries.

The model is designed to estimate the replacement value of trees in an urban environment. For most urban situations, the costs of planting and establishing the trees are small in relation to the LITA value, so excluding these costs is not a major issue, but the planting costs in common urban environments are nonetheless included. This is the correct approach unless the location involves major problems for tree planting (e.g., if specialist and expensive equipment is needed). The cost of such work is not included in the model and must be added separately for each such case. 


\section{CONCLUSIONS}

The Linear Index of Tree Appraisal model presented here uses tree cross-sectional area to extrapolate from a band of known prices to a base price for any desired tree size, which can then be adjusted using an appropriate factor depending on the vitality/ damage of the tree. It provides a simple method for determining the replacement cost of urban trees and is thus designed to work where soft values are sometimes difficult to justify. It is thus a good compromise between simplicity and accurately describing the change in tree price. The LITA model is easy to use, easy to update, does not have any limitations concerning tree species or sizes, and does not rely on subjective judgments except in assessing damage.

\section{LITERATURE CITED}

Alcamo, J., R. Hassan, and E. Bennett. 2003. Ecosystems and human well-being: A framework for assessment/Millennium Ecosystem Assessment. J. Alcamo (Ed.). Washington, D.C.

Aldén, B., and S. Ryman. 2009. Cultivated Plant Names (Våra Kulturväxters Namn), Formas, Stockholm, Sweden.

Ball, J., S. Mason, A. Kiesz, D. McCormick, and C. Brown. 2007. Assessing the hazard of emerald ash borer and other exotic stressors to community forests. Arboriculture \& Urban Forestry 5(33):350-359.

Bergin v Geisel. 2009. Case T4873-9. District Court. Sweden.

Bergin v Geisel. 2010. Case T12643-09. Court of Appeals. Sweden.

Bolund, P., and S. Hunhammar. 1999. Ecosystem services in urban areas. Ecological Economics 29(2):293-301.

Bulír, P. 2009. Testing of Koch method applied for evaluation of ornamental trees in the Czech Republic. Hortscience 5(36):154-161.

CAVAT. 2010. CAVAT-Full Method User Guide, The London Tree Officers Association.

CTLA. 2000. Council of Tree \& Landscape Appraisers: Guide for Plant Appraisal, ninth edition. International Society of Arboriculture, Champaign, Illinois, U.S.

Cullen, S. 2002. Tree appraisal: Can deprecation factors be rated greater than 100\%? Journal of Arboriculture 28(3):153-158.

Cullen, S. 2007. Putting a value on trees-CTLA guidance and methods. Arboricultural Journal 30(1):21-43.

Dimoudi, A., and M. Nikolopoulou. 2003. Vegetation in the urban environment: Microclimatic analysis and benefits. Energy and Buildings 35(1):69-76.

Dwyer, J.F., E.G. McPherson, H.W. Schroeder, and R. Rowntree. 1992. Assessing the benefits and costs of urban forest. Journal of Arboriculture 5(18):227-234.

Flook, R. 1996. A Standard Tree Evaluation Method: STEM.

Glaeser, C.W. 2010. The preservation and protection of urban trees: Lessons from the field from the city of New York. pp. 1063-1068. G. Prosdocimi, and A. Chiusoli (Eds.). Acta Horticulturae.

Hegedüs, A., M. Gaál, and R. Bérces. 2011. Tree appraisal methods and their application-First results in one of Budapest's districts. Applied Ecology and Environmental Research 9(4):411-423.
Helliwell, R. 1967. The amenity value of trees and woodlands. The Arboricultural Association Journal 1:128-131.

Helliwell, R. 2000. Amenity Valuation of Trees and Woodlands. R. Helliwell (Ed.). Arboricultural Association, Romsey, Hants, United Kingdom.

Helliwell, R. 2008. Amenity valuation of trees and woodlands. Arboricultural Journal 31(3):161-168.

i-Tree. 2012. i-Tree software. <www.itreetools.org>

Kinnard, W.M. 1971. Income Property Valuation, Lexington.

KP-Kallyl. 2012. KP System (KP systems). <www.kpsystem.se>

Kuchelmeister, G. 2000. Trees for the urban millennium: Urban forestry update. Unasylva 200(51):49-55.

Lämna v Tellstig. 2008. Case T5163-07. District Court. Sweden.

Lämna v Tellstig. 2010. Case T8226-08. Court of Appeals. Sweden.

Lewis, C.E. 1970. Shade Tree Evaluation, Revision II. In: C.E. Lewis (Ed.). International Shade Tree Conference Urbana, Illinois, U.S.

McMillan, R.C. 1964. The value of trees in the modern landscape. Trees 25(4):6-9.

McPherson, E.G., and P.P. Peper. 1996. Costs of street tree damage to infrastructure. Arboricultural Journal 20(2):143-160.

McPherson, E.G., D. Nowak, G. Heisler, S. Grimmond, C. Souch, R. Grant, and R. Rowntree. 1997. Quantifying urban forest structure, function, and value: The Chicago urban forest climate project. Urban Ecosystems 1(1):49-61.

Moore, G.M. 1992. Amenity Tree Evaluation: A Revised Method. In: The Scientific Management of Plants in the Urban Environment, Burnley Centenary Conference, Centre for Urban Horticulture, Melbourne, Australia. pp. 166-171.

Nowak, D., D.E. Crane, and J.F. Dwyer. 2002. Compensatory value of urban trees in the united states. Journal of Arboriculture 28(4):194-199.

Nowak, D.J., D.E. Crane, and J.C. Stevens. 2006. Air pollution removal by urban trees and shrubs in the United States. Urban Forestry \& Urban Greening 4(3-4):115-123.

Nowak, D.J., D.E. Crane, J.C. Stevens, R.E. Hoehn, J.T. Walton, and J. Bond. 2008. A ground-based method of assessing urban forest structure and ecosystem services. Arboriculture \& Urban Forestry 34(6):347-358

Nowak, D.J., J.E. Pasek, R.A. Sequeira, D.E. Crane, and V.C. Mastro. 2001b. Potential effect of Anoplophora glabripennis (Coleoptera: Cerambycidae) on urban trees in the United States. Journal of Economic Entomology 94(1):116-122.

Nowak, D.J., M.H. Noble, S.M. Sisinni, and J.F. Dwyer. 2001a. People and trees-Assessing the U.S. urban forest resource. Journal of Forestry 99(3):37-42.

Östberg, J., T. Delshammar, A.M. Fransson, and A.B. Nielsen. 2012. Standard för trädinventering i urban miljö (Standard for Tree inventories in urban environments). In: J. Östberg (Ed.). Department of Landscape Management, Design and Construction, LTJ-faculty. LTJ-fakulteten, Alnarp, Sweden.

Pohland v Värnamo municipality. 2012. Case T 3757-11. District Court. Sweden.

Price, C. 1995. Economic evaluation of financial and non-financial costs and benefits in agroforestry development and the value of sustainability. Agroforestry Systems 30(1-2):75-86.

Randrup, T.B. 2005. Development of a Danish model for plant appraisal. Journal of Arboriculture 31(3):114-123. 
Raupp, M.J., A.B. Cumming, and E.C. Raupp. 2006. Street tree diversity in eastern North America and its potential for tree loss to exotic borers. Arboriculture \& Urban Forestry 32(6):297-304.

Sjöman, H., J. Östberg, and O. Bühler. 2012. Diversity and distribution of the urban tree population in ten major Nordic cities. Urban Forestry \& Urban Greening 11(1):31-39.

Todorova, A., S. Asakawa, and T. Aikoh. 2004. Preferences for and attitudes towards street flowers and trees in Sapporo, Japan. Landscape and Urban Planning 69(4):403-416.

Watson, G. 2002. Comparing formula methods of tree appraisal. Journal of Arboriculture 28(1):11-18.

Xiao, Q., and E.G. McPherson. 2002. Rainfall interception by Santa Monica's municipal urban forest. Urban Ecosystems 6(4):291-302.

Yokohari, M., R.D. Brown, Y. Kato, and S. Yamamoto. 2001. The cooling effect of paddy fields on summertime air temperature in residential Tokyo, Japan. Landscape and Urban Planning 53(1-4):17-27.

Zhang, Y., and B. Zheng. 2011. Assessments of citizen willingness to support urban forestry: An empirical study in Alabama. Arboriculture \& Urban Forestry 37(3):118-125.

\author{
Johan Östberg (corresponding author) \\ Landscape Architecture, Planning and Management \\ P.O. Box 66, Alnarp SE-230 53 \\ Sweden
}

\section{Johan Sjögren \\ MAX IV Laboratory \\ Lund \\ Sweden}

Résumé. La valeur économique que constituent les arbres urbains est importante pour leur gestion et assurer que ces arbres seront maintenus et préservés. Cependant, de nombreux modèles sont actuellement disponibles afin d'établir la valeur de ces arbres, ce qui a conduit à une grande fluctuation de leur valeur définitive. Il a également donné lieu à de multiples modèles utilisés dans un même pays, générant ainsi une certaine confusion dans les tribunaux. Dans ce contexte, des chercheurs ont analysé si la surface terrière du tronc de l'arbre doit être utilisée de manière linéaire comme base de l'extrapolation pour établir la valeur de remplacement de l'arbre. Les chercheurs ont également mis au point un modèle, le Modèle de l'indice linéaire de lévaluation des arbres (LITA), qui utilise la surface terrière de l'arbre pour ensuite extrapoler à partir d'une liste de prix établis, un prix de base pour tout arbre nonobstant sa dimension, qui peut ensuite être ajusté en utilisant un facteur approprié prenant en compte la vigueur des arbres et leur état/condition.

Le modèle de l'indice linéaire de l'évaluation des arbres est facile à utiliser et à actualiser, ne comporte pas de limitations quant à l'espèce et à la dimensions des arbres, et ne repose pas sur des jugements subjectifs, sauf pour l'évaluation de l'état et de la condition des arbres évalués. Il fournit une méthode simple afin de déterminer le coût de remplacement des arbres et est donc conçu pour être utilisé lorsqu'une approche indulgente ou modérée est parfois difficile à justifier.

Zusammenfassung. Die ökonomische Bewertung von urbanen Bäumen ist für ihre Verwaltung wichtig und sichert dabei, dass solche Bäume gepflegt und geschützt werden können. Trotzdem sind derzeit zahlreiche Modelle zur Bewertung urbaner Bäume erhältlich, was zu einer großen Variation des finalen Preises führt. Es hat auch dazu geführt, dass innerhalb eines Landes verschiedene Modelle genutzt werden und die Gerichte verunsichert. Vor diesem Hintergrund untersuchen Wissenschaftler, ob die horizontale Querschnittfläche eines Baumes als Basis für eine Hochrechnung von Baumersatzkosten in einer linearen Weise verwendet werden kann. Die Forscher entwickelten auch ein Modell (Linearer Index der Baumschätzung) (LITA-Modell), welches die Baumquerschnittfläche als Basisgröße verwendet, um aus einer Auswahl von bekannten Preisen einen Preis für jede beliebige Größe hochzurechnen, welcher dann unter Einbezug eines entsprechenden Faktors in Abhängigkeit von der Baumgesundheit angepasst werden kann.

Das LITA-Modell ist leicht zu verwenden und zu aktualisieren, hat keine Einschränkungen bezüglich Baumart oder -größe und basiert nicht auf subjektiven Einschätzungen außer bei der Untersuchung von Baumschäden.

Resumen. La valoración económica de los árboles urbanos es importante para su gestión y para asegurar que este tipo de árboles sean mantenidos y protegidos. Sin embargo, numerosos modelos de valoración de los árboles urbanos están actualmente disponibles, lo que ha dado lugar a una gran variación en el precio final. También ha dado lugar a múltiples modelos que se utilizan dentro de un mismo país, confundiendo así a los tribunales. En este contexto, los investigadores examinaron si el área de la sección transversal del árbol se debe utilizar como base para la extrapolación del costo de reemplazo del árbol en una forma lineal. Los investigadores también desarrollaron un modelo, el Índice Lineal de Tasación del Árbol (LITA, por sus siglas en inglés), que utiliza el área de la sección transversal para extrapolar a partir de una banda de precios conocidos a un precio base para cualquier tamaño del árbol deseado, que luego se puede ajustar usando un factor apropiado que depende de la vitalidad/daño del árbol.

El modelo LITA es fácil de usar y de actualizar, no tiene ninguna limitación en relación con las especies de árboles o tamaños, y no se basa en juicios subjetivos, excepto en la evaluación de los daños a los árboles. Proporciona un método sencillo para determinar el costo de reposición de los árboles urbanos y por lo tanto está diseñado para trabajar donde los valores "suaves" son a veces difíciles de justificar. 